\title{
CHARACTERIZATION OF THE COFFEE FRUIT DETACHMENT FORCE IN CROP SUBJECTED TO MECHANIZED HARVESTING
}

\author{
Luiz de Gonzaga Ferreira Júnior ${ }^{1}$, Fábio Moreira da Silva², Danton Diego Ferreira², \\ Sérgio Domingos Simão ${ }^{4}$, Gabrielly Carvalho de Souza ${ }^{5}$, Lucas Kemps Ferreira ${ }^{6}$
}

(Received: January 3, 2017; accepted: Tuesday, May 2, 2017)

\begin{abstract}
In order to adjust the coffee harvester and to assist in deciding either whether or not to make a second pass of the harvester, fully or selectively, it is necessary to know some crop parameters. The aim of the present study was to evaluate the coffee fruit detachment force in the green and cherry ripeness, under different plant positions and in four evaluation periods, throughout the harvest period between the first and second pass of harvester. The cultivar used was the Catuaí Amarelo IAC 144 aged eight years in spacing $3.8 \times 0.9 \mathrm{~m}$. Detachment force was determined by sampling using a portable digital dynamometer. The green ripeness stage showed superior detachment force than the cherry for all evaluation periods. The fruit detachment force for the green and cherry ripeness showed a decreasing behavior during the evaluation period, since the difference between the detachment forces of these fruits increased, thus guiding the type of harvest to be performed. Beyond the fruit detachment force difference, other parameters such as fruit ripening rate and crop load were essential for harvest management. Significant variations were identified in the fruit detachment force positioned in different parts of the coffee tree branches. The results also reinforce the relevance of characterizing the coffee fruit detachment force for harvester adjustments and management of the selective mechanized harvesting.
\end{abstract}

Index terms: Coffea arabica L., selective mechanized harvesting, ripeness.

\section{CARACTERIZAÇÃO DA FORÇA DE DESPRENDIMENTO DOS FRUTOS DE CAFEEIROS EM LAVOURA SUBMETIDA À COLHEITA MECÂNICA}

RESUMO: Para adequação das regulagens de colhedoras de café e auxiliar na decisão sobre se fazer uma segunda passada da colhedora, de forma plena ou seletiva, é necessário conhecer alguns parâmetros da cultura. Este trabalho foi conduzido com o objetivo de avaliar a força de desprendimento dos frutos de café nas maturações verde e cereja, em diferentes posições na planta e em quatro épocas de avaliação, compreendidas no período de colheita entre a primeira e segunda passada da colhedora. A cultivar utilizada foi a Catuaí vermelho IAC 144, com 8 anos de idade, no espaçamento 3,8 x 0,9 m. A determinação da força de desprendimento foi realizada através de amostragem utilizando um dinamômetro digital portátil. O estádio de maturação verde apresentou força de desprendimento superior ao cereja, para todas as épocas de avaliação. A força de desprendimento dos frutos para as maturações verde e cereja apresentou comportamento decrescente ao longo do período de avaliação, já a diferença entre as forças de desprendimento desses frutos aumentaram, orientando assim no tipo de colheita a ser realizada. Além da diferença na força de desprendimento dos frutos, outros parâmetros como proporção da maturação dos frutos e carga pendente da lavoura se apresentaram essenciais para o gerenciamento da colheita. Foi possível identificar variações significativas na força de desprendimento dos frutos posicionados em diferentes partes dos ramos do cafeeiro. Os resultados reforçam ainda a importância da caracterização da força de desprendimento dos frutos de café para ajustes da colhedora e gerenciamento da operação de colheita seletiva mecânica.

Termos para indexação: Coffea arábica L., colheita seletiva mecanizada, maturação.

\section{INTRODUCTION}

The coffee is noteworthy worldwide for its socioeconomic importance in the most diverse sectors, being a product present for domestic consumption (FERREIRA JUNIOR et al., 2016). Coffee growing is highly relevant for the Brazilian economy (SILVA et al., 2015) and, according to Trabaquini et al. (2010), is considered the base of the economy of several municipalities and regions of the country, although its cultivation has a high production cost (RIBEIRO et al., 2009).
The low labor availability for coffee cultivation, especially for the harvesting process that requires a great variety of services available in a short period (SILVA et al., 2014), the search for reducing the operating costs and improving the quality of final product have strengthened the use of mechanized harvesting, with more than one pass of harvester seeking the selectivity of harvested fruits (CUNHA et al., 2016; OLIVEIRA et al., 2007a; SILVA et al., 2000).

\footnotetext{
1,2,3,5ederal University of Lavras/UFLA - Department of Engineering/DEG - Cx. P. 3037 - 37.200-000- Lavras - MG -luizdgfj@gmail.com, famsilva@deg.ufla.br, danton@deg.ufla.br, gabriellysouza_16@hotmail.com ${ }^{4}$ Federal University of Lavras/UFLA - Department of Exact Sciences/DEX- Cx. P. 3037 - 37.200-000 - Lavras - MG sergiodomingos12@zootecnista.com.br

${ }^{6}$ Federal University of Lavras/UFLA - Department of Animal Science/DZO - Cx. P. 3037 - 37.200-000 - Lavras - MG lucaskemps18@gmail.com
} 
In the selective harvesting, it is sought to collect only ripe fruits, leaving the green fruits in the plant. It requires higher operating speed and hence allows greater effective field capacity (CUNHA; SILVA; DIAS, 2016).

Selective mechanized harvesting of coffee provides batches that are more homogeneous, with greater maturation uniformity, favoring the postharvest process and allowing best final quality of the product.

According to Ferraz et al. (2012), one of the major difficulties for producers is determining the appropriate time to begin the harvest due to the plant shape, ripeness uniformity and the high water content of fruits, precluding the mechanized operation once the fruit is collected by vibration.

According to Silva et al. (2010), the fruit detachment force differs between green and cherry fruits, among cultivars and throughout the maturation period. Silva et al. (2013) showed that this force is an objective parameter that indicate the best time to start harvesting and a possible parameter for selective or full mechanized harvest management of the coffee plantation. Such detachment force is measured based on Hooke's Law, correlating the deformation of bodies with the force exerted on it, so that the force is proportional to the displacement from its equilibrium point (SILVA et al., 2010).

The mechanized harvesting of coffee is based on the vibration of harvester shank in contact with branches and fruits of the coffee tree. The inertial forces are applied to the fruit and overcome the stem attachment forces, resulting in the fruit detachment (ARISTIZÁBAL; OLIVEROS; ALVARES, 2003; OLIVEIRA et al., 2007b; SOUZA; QUEIROZ; RAFULL, 2006).

For Coelho et al. (2016), the natural frequencies of fruit-stem and fruit-stem-branch systems show a decreasing trend in response to the evolution of maturation process. The same authors state that the process of selective harvesting by mechanical vibration may become impossible when there is overlap of natural frequencies relatively to the green and ripe phases due to the variation in the physical and mechanical properties of the fruit peduncle system.

Ferreira Júnior, Silva and Ferreira (2016) reinforce the importance of understanding the behavior of harvest systems, i.e., the mechanical components of the harvester responsible for the transmission of vibration to the coffee fruits.
The knowledge on the trajectory performed by the coffee harvester shanks, besides their vibration amplitudes, effectively contributes to a better harvester adjustment (FERREIRA JÚNIOR; SILVA; FERREIRA, 2016). However, in order to develop efficient harvesters, it is necessary to understand the dynamic behavior of plant or parts to be harvested.

The present study aimed to evaluate the detachment force of coffee fruits (green and cherry) throughout the harvest period between the first and second pass of harvester and under different positions of the fruit in the plant, aiming to obtain information that aid in the management of selective mechanized harvesting of coffee.

\section{MATERIAL AND METHODS}

The experiment was performed during the 2016 harvest at Bela Vista Farm in the municipality of Nepomuceno, southern of the state of Minas Gerais, Brazil in a coffee area of 2.6 ha, whose geographical coordinates of the center area are $21^{\circ} 21^{\prime} 29.64^{\prime \prime} \mathrm{S}, 45^{\circ} 17^{\prime} 34.53^{\prime \prime} \mathrm{W}$, and $958 \mathrm{~m}$ altitude. The cultivar used in the evaluations was the Catuaí IAC 144 (Coffea arabica L.), planted in January 2008 with $3.80 \mathrm{~m}$ spacing between streets and $0.90 \mathrm{~m}$ between plants. The average height of plants was $2.20 \mathrm{~m}$ and average canopy width of $1.10 \mathrm{~m}$.

Generally, the mechanized harvest with self-propelling harvester is used in the property, performing two or more passes of the harvester in a same plot. The ripeness of fruits is the criterion used to decide when to start the first and second pass of the harvester.

The sampling for determination of crop load was performed in five points distributed within the area, containing five plants from a same line every plot. The manual harvest was performed on cloth, followed by the average volume of fruits harvested in liters per plant for each point and later the average between the crop load of five points. The ripening rate for each sample was obtained by taking two $0.5 \mathrm{~L}$ samples of fruits harvested at each point (CARVALHO et al., 2003; SILVA, 2008; SILVA et al., 2015), separating the green, cherry, and raisin and/or dried fruits, Subsequently, the average of those ripeness were performed for the 10 collected samples. Although raisin and dried fruits are from different ripeness stages, they are considered as buoyant fruits in the postharvest process and they easily detach from the branches during harvesting, thus being added and quantified as a single ripeness (raisins and/or dried). 
Before the first pass, the crop had an average crop load of 7.6 L per plant and ripeness of $42.5 \%$ green, $23.7 \%$ cherry and $33.8 \%$ raisins and dried fruits. On the second pass of the harvester, the crop showed an average crop load of $4.0 \mathrm{~L}$ per plant and ripeness of $10.9 \%$ green, $52.8 \%$ cherry and $36.3 \%$ raisins and dried fruits.

The evaluations occurred for 29 days between the first and second pass of the harvester, and were divided into 7-day intervals, called evaluation periods, being the periods 1, 2, 3 and 4 corresponding to days July 14, July 21, July 28 and August 3, respectively.

The experimental design was the completely randomized design (DIC) within a single plot, in random plots containing five plants. A split-plot in time was designed, being two positions and two ripeness types with 20 repetitions each.

For each plant, the coffee fruit detachment force (FDF) was measured for green and cherry ripeness. The FDF was determined using a Portable Digital Dynamometer manufactured and marketed by the company Instruterm, model DD 200.

The determination of the FDF of green and cherry fruits, as well as the behavior of this force in fruits from different parts along the plant height become essential for harvester adjustments in the selective mechanized harvesting.

Thus, the FDF of each demarcated plant was performed in two parts of the plant: upper middle (U) and lower middle (L) of the plant. These parts were taken on two sides of the plant: the east and the west side of the same (perpendicular to the planting line). Moreover, the FDF of eight coffee fruits per plant were evaluated, being two green fruits and two cherry fruits both in the upper middle and in the lower middle of the plant.

During the first three evaluations, a difference in the volume of fruits that remained in the primary and secondary branches after the first pass of harvester was observed. Therefore, the FDF (green and cherry) was evaluated only in the last collection period (4), under the same conditions ( $\mathrm{U}$ and $\mathrm{L}$ parts of the plant), but in the fruits of the primary $(\mathrm{P})$ and secondary $(\mathrm{S})$ plagiotropic branches.

The data collected in the field were organized in a spreadsheet in order to determine the average and the coefficient of variation of the FDF replications, within each evaluated ripeness stage.
The analyses were performed in a split-plot in time with the R statistical software (R CORE TEAM, 2016). The statistical model for the splitplot design in CRD for the FDF variable is given by (HINKELMANN; KEMPTHORNE, 2008):

$y_{i j k l}=\mu+\alpha_{i}+\beta_{j}+\alpha \beta_{i j}+\gamma_{l(j)}+\delta_{k}+\alpha \delta_{i k}+\beta \delta_{j k}+\alpha \beta \delta_{i j k}+\varepsilon_{i j k,}(1)$

where,

$y_{i j k}$ is the observed value of the detachment force variable of the $i$-th position in the $j$-th ripeness stage in the $k$-th evaluation period in the $l$-th repetition, with $i=1,2, j=1$, $2, k=1,2,3,4$ and $l=1,2, \ldots 20$;

$\mu$ is a constant inherent to all the observations;

$\alpha_{i}$ is the effect of the $i$-th position; stage;

$\beta_{i k} \beta_{i k} \beta_{j}$ is the effect of the $j$-th ripeness

$\alpha \beta_{i j}$ is the effect of the position $\mathrm{x}$ ripeness stage interaction; level;

$\gamma_{l(i j)}$ is the experimental error at plot period;

$\delta_{k}$ is the effect of the $k$-th evaluation

$\alpha \delta_{i k}$ is the effect of the position $\mathrm{x}$ evaluation period interaction;

$\beta \delta_{j k}$ is the effect of the ripeness stage $\mathrm{x}$ evaluation period interaction;

$\alpha \beta \delta_{i j k}$ is the effect of the position $\mathrm{x}$ ripeness stage $\mathrm{x}$ evaluation period interaction; $\varepsilon_{i j k l}$ is the experimental error at subplot level.

\section{RESULTS AND DISCUSSION}

The results of the FDF effect for the green and cherry ripeness in the lower and upper positions referring to the four evaluation periods are presented in Table 1. No significant difference was observed in the interaction between ripeness stage $(\mathrm{R}) \mathrm{x}$ position $(\mathrm{P})$ and evaluation period $(\mathrm{EP})$, with $p$-value $=0.9620$ as well as for the double interactions ripeness stage $(R) x$ position $(P)$, with $\mathrm{p}$-value $=0.2611$; ripeness stage $(\mathrm{R}) \mathrm{x}$ evaluation period (EP), with $\mathrm{p}$-value $=0.3140$; and position (P) $\mathrm{x}$ evaluation period (EP), with $\mathrm{p}$-value $=0.8170$. There was no significant difference between the positions with $\mathrm{p}$ value $=0.0929$; for the ripeness stage, there was a significant difference, with p-value $<2$ x 10-16; finally, there was a significant effect for each evaluation period, with $\mathrm{p}$-value $=7.51 \times 10-10$ for the FDF variable of Coffea arabica cv. Catuaí Vermelho (Table 1). 
TABLE 1 - Effect of FDF on different ripeness stages (green and cherry) and positions in the plant (lower and upper) for the cultivar Catuaí Vermelho referring to the four evaluation periods.

\begin{tabular}{|c|c|c|c|c|c|c|}
\hline \multirow[b]{2}{*}{ Factor } & & \multicolumn{4}{|c|}{ Evaluation period } & \multirow{2}{*}{ Overall average $^{1}$} \\
\hline & & 1 & 2 & 3 & 4 & \\
\hline \multirow{3}{*}{ Ripeness (R) } & Green (G) & 8.32 & 8.38 & 7.08 & 7.04 & $7.71 \mathrm{a}$ \\
\hline & Cherry (C) & 5.52 & 5.08 & 3.46 & 3.00 & $4.27 \mathrm{~b}$ \\
\hline & $\begin{array}{l}\text { Force difference } \\
\text { (FD) }\end{array}$ & 2.8 & 3.3 & 3.62 & 4.04 & 3.44 \\
\hline \multirow[b]{2}{*}{ Position (P) } & Lower (L) & 6.76 & 6.75 & 5.05 & 4.73 & $5.82 \mathrm{a}$ \\
\hline & Upper (U) & 7.09 & 6.72 & 5.50 & 5.32 & $6.15 \mathrm{a}$ \\
\hline \multicolumn{2}{|c|}{ Evaluation period $(\mathrm{EP})^{2}$} & $6.92 \mathrm{a}$ & $6.73 \mathrm{~b}$ & $5.27 \mathrm{c}$ & $5.02 \mathrm{~d}$ & \\
\hline \multicolumn{7}{|c|}{ Significance levels of the F test (p-values) } \\
\hline \multicolumn{2}{|c|}{ Factors } & \multicolumn{4}{|c|}{$\mathrm{F}$} & P-Value \\
\hline \multicolumn{2}{|c|}{$\mathrm{R}$} & \multicolumn{4}{|c|}{305.47} & $<2 \times 10^{-16^{*}}$ \\
\hline \multicolumn{2}{|c|}{$\mathrm{P}$} & \multicolumn{4}{|c|}{2.89} & $0.0929^{\text {ns }}$ \\
\hline \multicolumn{2}{|c|}{ EP } & \multicolumn{4}{|c|}{16.71} & $7.51 \times 10^{-10^{*}}$ \\
\hline \multicolumn{2}{|c|}{$\mathrm{R} \times \mathrm{P}$} & \multicolumn{4}{|c|}{1.28} & $0.2611^{\mathrm{ns}}$ \\
\hline \multicolumn{2}{|c|}{$\mathrm{R} \times \mathrm{EP}$} & \multicolumn{4}{|c|}{1.19} & $0.3140^{\text {ns }}$ \\
\hline \multicolumn{2}{|c|}{$\mathrm{P} \times \mathrm{EP}$} & \multicolumn{4}{|c|}{0.31} & $0.8170^{\text {ns }}$ \\
\hline \multicolumn{2}{|c|}{$\mathrm{R} \times \mathrm{P} \times \mathrm{EP}$} & \multicolumn{4}{|c|}{0.09} & $0.9620^{\mathrm{ns}}$ \\
\hline
\end{tabular}

${ }^{1}$ Averages followed by different letters on the columns are statistically different by Tukey test $(\mathrm{P}<0.05) .{ }^{2}$ Averages followed by different letters on the rows are statistically different by Tukey test $(\mathrm{P}<0.05)$. ${ }^{\text {ns }}$ : not significant at $5 \%$ by $\mathrm{F}$ test; *: significant at $5 \%$ by $\mathrm{F}$ test.

It can be verified that the average detachment force between the green and cherry ripeness stages differed significantly by Tukey test. The green ripeness stage showed a higher average FDF value in relation to the cherry, corroborating with the results obtained by Silva $(2008,2012)$ and Silva et al. $(2010,2013,2016)$.

Silva et al. (2010) evaluated the FDF of the coffee tree for five periods along a harvest and observed that the average detachment force of green and cherries fruits was $9.6 \mathrm{~N}$ and 6.36 $\mathrm{N}$, respectively, for the same cultivar (Catuai Vermelho 144). The detachment forces found in the present study showed lower average values (around $2 \mathrm{~N}$ ) than the found by Silva et al. (2010) for both ripeness evaluated (Table 1). This may have been a consequence of different climate conditions, the flowering or collection season, plant nutritional status and small variation of the dynamometer position in relation to the sampled fruit (Silva et al., 2013, 2016).

The average FDF value for each evaluation period throughout the evaluation periods reduced from $6.92 \mathrm{~N}$ to $5.02 \mathrm{~N}$, according to the Tukey test (Table 1).
In Figure 1 is shown the average FDF values for green and cherry ripeness stages and the difference with each other throughout the evaluation periods.

Despite the non-significance of the ripeness stage $\mathrm{x}$ evaluation period interaction, a greater reduction in the average value of the force between the evaluation periods 2 and 3 was observed in Figure 1, decreasing from 8.37 to $7.08 \mathrm{~N}$ for the green and from 5.08 to $3.46 \mathrm{~N}$ for the cherry fruits.

In Table 1 is presented that green and cherry FDF values decreased throughout the evaluation periods, reducing from 8.32 to $7.04 \mathrm{~N}$ for green and from 5.52 to $3.00 \mathrm{~N}$ for cherry ripeness. The FDF difference between the green and cherry ripeness showed increasing values during the evaluation periods due to the lower ripening rate of green fruits in relation to the cherries. This behavior is evidenced in Figure 1.

It is worth pointing out that, among the performed evaluations, the evaluation period 4 showed a higher average value in the difference between green and cherry FDF $(4.04 \mathrm{~N})$, a behavior 
that according to Silva et al. (2016) enhances the selective and mechanized harvesting, since this parameter becomes a selectivity criterion between the fruit ripeness, favoring the removal of cherry fruits of the plant.

Such criterion can aid in the difficulty faced by coffee growers in defining the best time to start the harvesting, cited by Ferraz et al. (2012). Other situations that can be favored, in which the coffee growers also present difficulties, is in defining for full or selective harvesting and in defining how many times the harvester must pass in the crop.

Silva (2008), through experimentation, defined as a parameter to aid in the decision for full or selective harvesting, the average value of the detachment force difference between green and cherry fruits, being $3.0 \mathrm{~N}$ the parameter value of difference; if the difference found is above this value, selective harvesting is recommended, otherwise, full harvesting is indicated.

In the present study, evaluation periods 2,3 , and 4 showed average values in the FDF difference above $3.0 \mathrm{~N}$ (Table 1) and, based on the Silva parameter (2008), a selective harvesting would be indicated for these three evaluations.

Taking into account that the average value of the difference between green and cherry FDF increased throughout the evaluation periods (Figure 1), other parameters that supported the decision-making were the rate of green fruits present in the crop at that time and the crop load. At evaluation period 4 , although the force difference between the ripeness was $4.04 \mathrm{~N}$, the crop showed $10.2 \%$ green fruits and $75.4 \%$ ripe fruits for an average crop load of $3.6 \mathrm{~L}$ per plant, being not viable for the producer to perform a selective harvesting in the second pass of the harvester, thus opting for the full harvest.
In the condition of few green fruits as presented in the evaluation period 4 , a second pass of the harvester selectively would tend to leave few fruits in the plant for the third pass, which could not be profitable.

Thus, besides studying the difference in the detachment force between green and cherry fruits, other factors such as ripening rate and crop load should also be considered in decision-making for more than one pass of the harvester.

This information is extremely important for the management of mechanized harvesting of coffee, since it can be correlated with the recommendation results of mechanized harvesting based on the dynamic behavior of the vibrating shanks of the harvester, such as the results found by Ferreira Júnior, Silva and Ferreira (2016), showing differences in the ranges reached by vibrating shanks, varying the oscillator cylinder vibration, cylinder brake torque and shank length along this cylinder.

Souza et al. (2005) report that the influence of the ripeness stage on fruit detachment period indicates that the vibration time is a parameter that should be considered in the selective harvesting of coffee fruits.

In the selective mechanized harvesting, it is common to remove the shanks from part of vibrating cylinders precisely at the height when the plant has greater amount of green fruits, avoiding to harvest these fruits and seeking to harvest the maximum of cherry fruits. However, when fruit ripeness is non-uninform along the plant, this practice becomes unviable. The results of the present study indicated that it was not necessary to remove the shanks from the cylinders, since there was no significant difference of FDF between the upper and lower parts of the plant (Table 1).

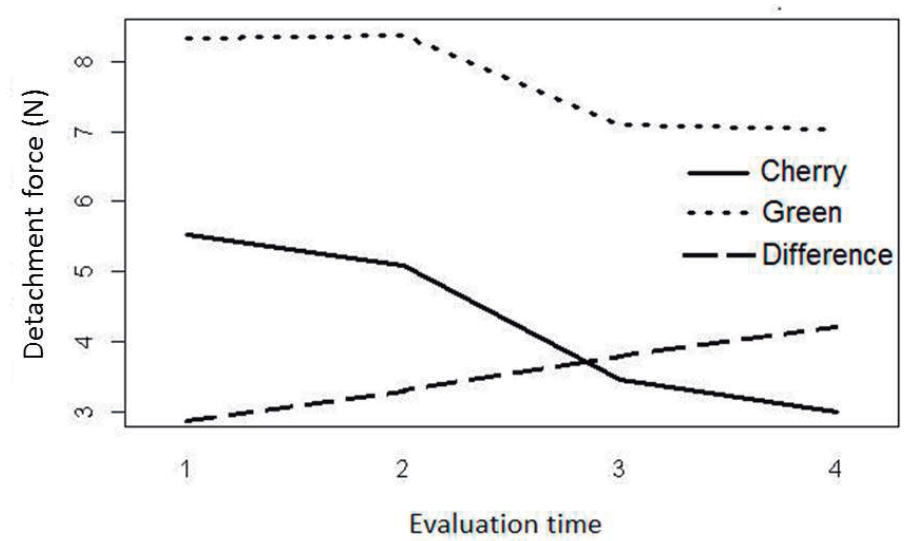

FIGURE 1 - Behavior of green and cherry FDF and the difference of such force among the evaluated stages throughout evaluation periods. 
The FDF behavior is characterized in Table 2 , showing average values for each ripeness stages in the studied plant positions and the difference in the average FDF value between the green and cherry ripeness stages.

The FDF difference between ripeness is presented in detail for the upper and lower parts of the plant, observing an increase throughout the evaluated periods (Table 2).

Important recommendations for the selective or full mechanized harvesting of coffee, such as the orientation of the arrangement of vibrating shanks along the cylinder and the shank sizes, can be influenced by characterizing the FDF throughout the plant.

When evaluating the FDF in first- and second-order plagiotropic branches (PB), there was no significant difference between the $U$ and $\mathrm{L}$ positions $(\mathrm{P})$, with $\mathrm{p}$-value $=0.09499$, and for the effect of ripeness stage $(\mathrm{R})$, there was significant difference with $\mathrm{p}$-value $<2 \times 10^{-16}$. However, no significant difference was found for the position (P) $x$ ripeness stage $(\mathrm{R})$ interaction, with $\mathrm{p}$-value $=0.3257$. For the effect of plagiotropic branches (PB), there was significant difference, with $\mathrm{p}$-value $=0.000591$. No significant difference was found for the position $(\mathrm{P}) \mathrm{x}$ plagiotropic branch $(\mathrm{PB})$ interaction, with $\mathrm{p}$-value $=0.414946$, nor for the ripeness stage $(\mathrm{R}) \mathrm{x}$ plagiotropic branch (PB) interaction, with $\mathrm{p}$-value $=0.731095$. There was also no significant difference for the triple interaction position $(\mathrm{P}) \mathrm{x}$ ripeness stage $(\mathrm{R}) \mathrm{x}$ plagiotropic branch $(\mathrm{PB})$, with $\mathrm{p}$-value $=0.743464$. Data are presented in Table 3.
The results showed that the second-order plagiotropic branches showed fruits with higher average values in the detachment force (Table 3), i.e., greater detachment resistance, being statistically different by Tukey test. On the other hand, the fruits from the first-order branches showed the lowest values of FDF.

In the green ripeness, the forces were $6.53 \mathrm{~N}$ and $7.54 \mathrm{~N}$ for fruits from the first- and second-order branches, respectively. In the cherry ripeness, the forces were $2.52 \mathrm{~N}$ and $3.36 \mathrm{~N}$ for fruits from the first- and second-order branches, respectively.

The characterization of green and cherry FDF in the different studied plant positions (L and $U$ ) and the average force difference between ripeness stages is generally presented in Table 4.

It was observed that these FDF differences between green and cherry ripeness exceeded the parameter value of $3.00 \mathrm{~N}$ suggested by Silva (2008) in both evaluated branches (F and S) and plant position (upper and lower) (Table 4).

The FDF behavior in the first- and secondorder order branches for the upper and lower parts is shown in Figure 2.

It is also possible to verify that the higher FDF were obtained for fruits positioned in secondorder branches and the smaller forces were obtained in the first-order branches (Figure 2).

There is coffee fruit detachment when the inertial forces resulting from movement in the fruit become greater than the tensile strength necessary to cause detachment (PARCHOMCHUK; COOKE, 1971).

TABLE 2 - Average FDF values of Catuaí cultivar in the green and cherry ripeness stages, at upper and lower plant positions and average value of the force difference between ripeness for the four evaluation periods.

Evaluation period

\begin{tabular}{|c|c|c|c|c|}
\hline Ripeness / Plant position & 1 & 2 & 3 & 4 \\
\hline Green / Upper & 8.53 & 8.43 & 7.51 & 7.47 \\
\hline Green / Lower & 8.13 & 8.32 & 6.67 & 6.60 \\
\hline Cherry / Upper & 5.66 & 5.00 & 3.49 & 3.16 \\
\hline Cherry / Lower & 5.39 & 5.18 & 3.44 & 2.85 \\
\hline $\begin{array}{l}\text { Force difference between } \\
\text { the green and cherry stages } \\
\text { positioned in the upper part }\end{array}$ & 2.87 & 3.43 & 4.02 & 4.31 \\
\hline $\begin{array}{l}\text { Force difference between } \\
\text { the green and cherry stages } \\
\text { positioned in the lower part }\end{array}$ & 2.74 & 3.14 & 3.23 & 3.75 \\
\hline
\end{tabular}


TABLE 3 - Effect of the FDF of coffee from the Catuaí Vermelho cultivar at different ripeness stages (green and cherry), plant positions (lower and upper) and in the different plagiotropic branches.

\begin{tabular}{|c|c|c|c|c|}
\hline \multirow[b]{2}{*}{ Factor } & & \multicolumn{2}{|c|}{ Plagiotropic branch } & \multirow{2}{*}{ Overall average } \\
\hline & & Primary & Secondary & \\
\hline \multirow[b]{2}{*}{ Ripeness (R) } & Green $(G)$ & 6.53 & 7.54 & $7.04 \mathrm{a}$ \\
\hline & $\begin{array}{c}\text { Cherry }(\mathrm{C}) \\
\text { Force difference } \\
\text { (FD) }\end{array}$ & $\begin{array}{l}2.52 \\
4.01\end{array}$ & $\begin{array}{l}3.36 \\
4.18\end{array}$ & $\begin{array}{c}2.94 b \\
4.99\end{array}$ \\
\hline \multirow[b]{2}{*}{ Position (P) } & Lower (L) & 4.36 & 5.07 & $4.71 \mathrm{a}$ \\
\hline & Upper (U) & 4.69 & 5.83 & $5.26 \mathrm{a}$ \\
\hline \multicolumn{2}{|c|}{ Plagiotropic branch $(\mathrm{PB})^{2}$} & $4.52 \mathrm{~b}$ & $5.45 \mathrm{a}$ & \\
\hline \multicolumn{5}{|c|}{ Significance levels of the F test (p-values) } \\
\hline \multicolumn{2}{|c|}{ Factors } & \multicolumn{2}{|c|}{$\mathrm{F}$} & P-Value \\
\hline \multicolumn{2}{|c|}{$\mathrm{R}$} & \multicolumn{2}{|c|}{158.069} & $<2 \times 10^{-16^{*}}$ \\
\hline \multicolumn{2}{|c|}{$\mathrm{P}$} & \multicolumn{2}{|c|}{2.860} & $0.09499^{\text {ns }}$ \\
\hline \multicolumn{2}{|c|}{$\mathrm{PB}$} & \multicolumn{2}{|c|}{12.859} & $0.000591^{*}$ \\
\hline \multicolumn{2}{|c|}{$\mathrm{R} \times \mathrm{P}$} & \multicolumn{2}{|c|}{0.978} & $0.3257^{\mathrm{ns}}$ \\
\hline \multicolumn{2}{|c|}{$\mathrm{R} \times \mathrm{PB}$} & \multicolumn{2}{|c|}{0.119} & $0.731095^{\text {ns }}$ \\
\hline \multicolumn{2}{|c|}{$\mathrm{P} \times \mathrm{PB}$} & \multicolumn{2}{|c|}{0.672} & $0.414946^{\text {ns }}$ \\
\hline \multicolumn{2}{|c|}{$\mathrm{R} \times \mathrm{P} \times \mathrm{PB}$} & \multicolumn{2}{|c|}{0.108} & $0.743464^{\text {ns }}$ \\
\hline
\end{tabular}

${ }^{1}$ Averages followed by different letters on the columns are statistically different by Tukey test $(\mathrm{P}<0.05) .{ }^{2}$ Averages followed by different letters on the rows are statistically different by Tukey test $(\mathrm{P}<0.05) .{ }^{\text {ns. }}$, not significant at $5 \%$ by $\mathrm{F}$ test; ${ }^{*}$ : significant at $5 \%$ by $\mathrm{F}$ test.

TABLE 4 - Average detachment force of coffee fruits from the Catuaí cultivar in the green and cherry ripeness stages, at the upper and lower middle position and in the first- and second-order plagiotropic branches.

\begin{tabular}{lcc}
\hline & \multicolumn{2}{c}{ Plagiotropic branch } \\
\cline { 2 - 3 } Ripeness / Plant position & First (F) & Second (S) \\
\hline Green / Upper & 6.90 & 8.05 \\
Green / Lower & 6.16 & 7.05 \\
Cherry / Upper & 2.49 & 3.62 \\
Cherry / Lower & 2.56 & 3.10 \\
Force difference between & & \\
the green and cherry stages & 4.41 & 4.43 \\
positioned in the upper part & & \\
& & \\
Force difference between & & 3.95 \\
the green and cherry stages & 3.60 & \\
positioned in the lower part & & \\
\hline
\end{tabular}




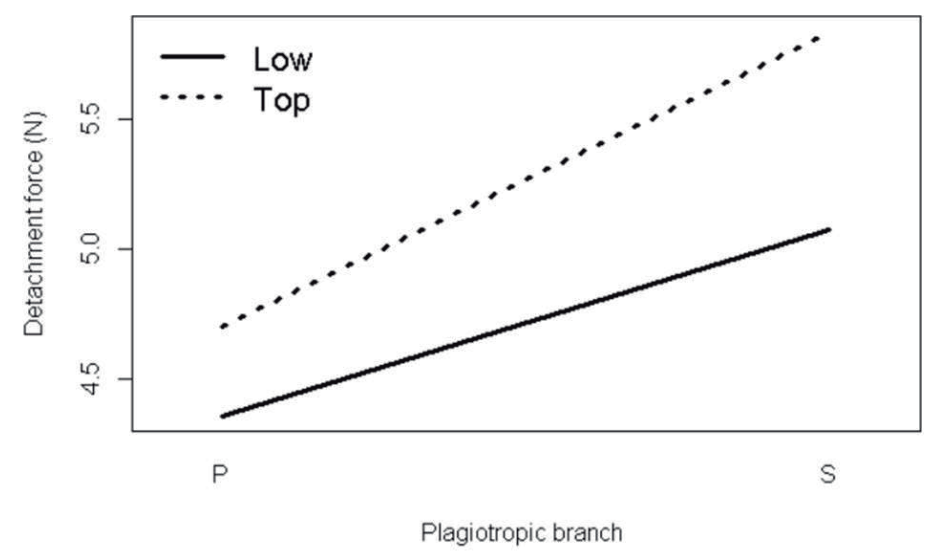

FIGURE 2 - FDF behavior in the first- (F) and second-order (S) branches for the upper and lower plant positions, regardless of fruit ripeness.

For the studied Catuaí cultivar, the results indicate the vibrational energy, i.e., the necessary tensile strength to harvest the fruits positioned in the second-order branches should be greater in relation to the first-order fruits, since its FDF was greater in relation to the fruits from the first-order branches.

However, there are still devices and resources in the coffee harvesters that provide harvesting by localized vibrational energy to the fruits in different branches of the plant. However, the study serves as basis for the development of new equipment and as guidance for a possible selective harvesting with portable harvesters, enabling "vibrating fingers" that directed to the desired position in the plant.

\section{CONCLUSIONS}

The average fruit detachment force for the green and cherry ripeness reduced throughout the evaluation periods, but the average value of the force difference between ripeness stages increased.

The average value of the detachment force difference between the green and cherry ripeness was considered together with the rate of green fruits present in the crop and mean crop load, being as a set of parameters that aid in the decision to perform the full harvest in the second pass, thus closing the harvest.

The fruits of the second-order plagiotropic branches were statistically different, showing the highest values for the detachment force in both ripeness stages.

\section{ACKNOWLEDGEMENTS}

The authors would like to thank the Coordination for the Improvement of Higher
Education Personnel (CAPES), the Foundation for Supporting Research of the State of Minas Gerais (FAPEMIG), and the National Council for Scientific and Technological Development $(\mathrm{CNPq})$ for cooperation and financial support.

\section{REFERENCES}

ARISTZÁBAL, I. D.; OLIVEROS, T. C. E.; ALVARES, M. F. Mechanica harvest of coffee applying circular and multidirectional vibrations. Transactions of the ASAE, Saint Joseph, v. 46, n. 2, p. 197-204, 2003.

CARVALHO, G. R. et al. Eficiência do Ethephon na uniformização e antecipação da maturação de frutos de cafeeiro (Coffea arabica L.) e na qualidade da bebida. Ciência e Agrotecnologia, Lavras, v. 27, n. 1, p. 98106, jan./fev. 2003.

COELHO, A. L. F. et al. Dynamic Behavior of the coffee fruit-stem-branch system using stochastic finite elemento method. Coffee Science, Lavras, v. 11, n. 1, p. 1-10, Jan./Mar. 2016.

CUNHA, J. P. B. et al. Viabilidade técnica e econômica de diferentes sistemas de colheita do café. Coffee Science, Lavras, v. 11, n. 3, p. 416-425, jul./set. 2016.

CUNHA, J. P. B.; SILVA, F. M.; DIAS, R. E. B. A. Eficiência de campo em diferentes operações mecanizadas na cafeicultura. Coffee Science, Lavras, v. 11, n. 1, p. 76-86, jan./mar. 2016.

FERRAZ, G. A. S. et al. Geostatistical analysis of fruit yield and detachment force in coffee. Precision Agriculture, Dordrecht, v. 13, n. 1, p. 76-89, Feb. 2012. 
FERREIRA JÚNIOR, L. G. et al. Recomendação para colheita mecânica do café baseado no comportamento de vibração das hastes derriçadoras. Ciência Rural, Santa Maria, v. 46, n. 2, p. 273-278, fev. 2016.

FERREIRA JÚNIOR, L. G.; SILVA, F. M.; FERREIRA, D. D. Displacement tracking of harvester rods of a coffee harvester. IEEE Latin America Transactions, New York, v. 14, n. 12, p. 4674-4680, Dec. 2016.

HINKELMANN, K.; KEMPTHORNE, O. Design and analysis of experiments: introduction to experimental design. $2^{\text {nd }}$ ed. New Jersey: J. Wiley, 2008. 631 p.

OLIVEIRA, E. et al. Custos operacionais da colheita mecanizada do cafeeiro. Pesquisa Agropecuária Brasileira, Brasília, DF, v. 42, n. 6, p. 827-831, jun. 2007a.

Influência da vibração das hastes e da velocidade de deslocamento da colhedora no processo de colheita mecanizada do café. Revista Engenharia Agrícola, Jaboticabal, v. 27, n. 3, p. 714-721, 2007 b.

PARCHOMCHUK, P.; COOKE, J. R. Vibratory fruit harvesting: na experimental analysis of fruit-stem dynamics. Transactions of the ASAE, Saint Joseph, v. 15, n. 4, p. 598-603, 1971.

R CORE TEAM. R: a language and environment for statistical computing. Vienna: R Foundation for Statistical Computing, 2016. Available from: <http:// www.R-project.org/>. Acesso em: 27 fev. 2016.

RIBEIRO, M. S. et al. Efeitos de águas residuárias de café no crescimento vegetativo de cafeeiros em seu primeiro ano. Engenharia Agrícola, Jaboticabal, v. 29, n. 4, p. 569-577, out./dez. 2009.

SILVA, F. C. Efeito da força de desprendimento e da maturação dos frutos de cafeeiros na colheita mecanizada. 2008. 106 p. Dissertação (Mestrado em Engenharia Agrícola)-Universidade Federal de Lavras, Lavras, 2008.

Influência de variáveis meteorológicas do solo e nutricionais na força de desprendimento dos frutos do café. 2012. 71 p. Tese (Doutorado em Engenharia Agrícola)-Universidade Federal de Lavras, Lavras, 2012.

SILVA, F. C. et al. Comportamento da força de desprendimento dos frutos de cafeeiros ao longo do período de colheita. Ciência e Agrotecnologia, Lavras, v. 34, n. 2, p. 468-474, mar./abr. 2010.

Correlação da força de desprendimento dos frutos em cafeeiros sob diferentes condições nutricionais. Coffee Science, Lavras, v. 11, n. 2, p. 169 179, abr./jun. 2016.

Desempenho operacional da colheita mecanizada e seletiva do café em função da força de desprendimento dos frutos. Coffee Science, Lavras, v. 8, n. 1, p. 53-60, jan./mar. 2013.

SILVA, F. M. et al. Custo da colheita mecanizada de café com colhedoras automotrizes no Sul de Minas. Engenharia na Agricultura, Viçosa, v. 8, n. 1, p. 5460, 2000.

Efficiency of coffee mechanical and selective harvesting in different vibration during harvest time. Coffee Science, Lavras, v. 10, n. 1, p. 56-64, jan./mar. 2015.

Mecanização da colheita viabiliza cafeicultor. A Granja, Porto Alegre, v. 784, p. 60-62, 2014.

SOUZA, C. M. A. et al. Desenvolvimento de uma máquina vibradora para estudo do desprendimento de frutos do cafeeiro. Engenharia Agrícola, Viçosa, v. 13, n. 1, p. 7-18. jan./mar. 2005.

SOUZA, C. M. A.; QUEIROZ, D. M.; RAFULL, L. Z. D. Derriçadora portátil na colheita total e seletiva de frutos do cafeeiro. Pesquisa Agropecuária Brasileira, Brasília, DF, v. 41, n. 11, p. 1637-1642, nov. 2006.

TRABAQUINI, K. et al. Uso da geotecnologia para caracterizar os cafezais no município de Londrina$\mathrm{PR}$, em relação à altimetria, declividade e tipo de solo. Revista Brasileira de Engenharia Agrícola, Jaboticabal, v. 30, n. 6, p. 1136-1147, nov./dez. 2010. 